\title{
The strategies for Russian higher education regionalization and internationalization
}

\author{
Elena Vasileva*, and Tatiana Zerchaninova \\ Russian Presidential Academy of National Economy and Public Administration, March 8 Str., 66, \\ 620144 Ekaterinburg, Russia
}

\begin{abstract}
Today the education internationalization has become one of the economy sectors in the developed countries; the export potential of Russian education is still largely underutilized. Until now, domestic and foreign scientific literature lacks a comprehensive study of state policies pursued by national states to develop the internationalization and/or regionalization. The study of internationalization policies tends to focus on in-depth case studies across two to three countries. However, studies with a narrow geographic scope, although they provide valuable information about this phenomenon, do not allow us to see a holistic picture. The article attempted to overcome the indicated gaps in scientific research by analyzing the strategies of higher education regionalization and internationalization at countries that occupy a large market share and formulate recommendations for Russia. The article argued that in the context of the Covid-19 pandemic, the priority area for the internationalization is the development of virtual mobility and internal internationalization and regionalization.
\end{abstract}

\section{Introduction}

Since 2017, the higher education internationalization has become an important component of the Russian educational policy in connection with the launch of the priority project "Development of the export potential of the Russian education system" [1], within which it is planned to increase the number of foreign students studying full-time at Russian universities and vocational schools. , three times - from 220 thousand people in 2017 to 710 thousand people in 2025, and the number of foreign students of online courses in Russian educational institutions should more than triple: from 1.1 million people to 3,5 million people.

The current period of development of the higher education internationalization is characterized by increased attention to cooperation at the regional level. As a consequence, there has been an increase in the number of regional university networks, regional student mobility programs and subregional higher education associations. The most famous

\footnotetext{
* Corresponding author: vasilyeva-ekb@yandex.ru
} 
example of regionalization is the Bologna Process in Europe. A review of initiatives in Africa, Asia and Latin America demonstrates the importance attributed to the higher education regionalization at the current stage. Nevertheless, it can be noted that the strategies of internationalization and regionalization coincide, the only difference is in the object - the whole world and a specific region, respectively.

Thus, the chosen research topic is relevant and is determined not only by the significance of the development of public administration in modern Russian conditions, but also by the need to develop organizational and legal frameworks and guidelines for organizing an effective strategy of higher education internationalization, which necessitates the use of research, including, and foreign experience.

\section{Literature review}

The export potential of education and the directions of its development are the subject of study of a significant range of disciplines. Within the framework of this direction, it is possible to single out such scientists as F. Altbach [2], M. de Wende, H. de Witt [3], N. Haley [4] and others.

Among domestic researchers, the issues of higher education internationalization were most actively studied by I.V. Abankina, A.A. Belikov, O.S. Gaponova, F.F. Dudyrev, Yu.N. Koreshnikova, I.A. Korshunov, S.G. Kosaretsky, T.A. Mertsalova, A.K. Nysskaya, D.P. Platonov, P.S. Sorokin, B.M. Talovskaya, I. D. Frumin [5], R.R. Asmyatullin [6], O.S., Vinokurova [7], A.N. Nefedova [8] and others.

Regionalization of higher education is a process of purposeful building of connections and relations between subjects of higher education, structure and systems within the region, and internationalization is for interaction in a global format.

The basic activities for the higher education internationalization include:

- creation of mechanisms to support the promotion of Russian education abroad;

- conducting information campaigns;

- development of a comprehensive plan for attracting foreign citizens;

- creation of specialized countries for reference groups to attract foreign students;

- creation of resource centers to attract foreign students.

The project, as well as the content of other regulatory documents, reflects only promising forms of work, the specified tasks have not been substantively worked out. For example, a comprehensive plan for attracting foreign students is planned to be developed only by the end of 2020. Thus, despite the consolidation of this task at the level of national priorities, the implementation of directions for the development of the export potential of Russian education remains a task for the future.

\section{Materials and methods}

The empirical basis for the study was statistical data and analytical reviews of the Institute for International Education (IIE), materials of a specialized resource for market research for the international education industry ICEF Monitor.

Also, the empirical base of the study was made up of the content of documents that allow to determine the institutional framework for the higher education internationalization. Were studied regulations and government programs (education internationalization strategies) in the analyzed countries.

The comparison was carried out according to the following parameters:

- regulatory framework for the higher education internationalization;

- organizational aspects of the higher education internationalization; 
- strategic goals and directions of higher education internationalization.

The methodology assumed the allocation of provisions, sections, targets and indicators of financing programs by keywords in the documents.

To analyze the Russian export of education, data from the Ministry of Science and Higher Education of the Russian Federation were used in the framework of regular monitoring of the contingent of foreign students and statistical accounting of the export of Russian educational services.

\section{Research results}

According to statistics, the level of mobility of foreign students is growing rapidly in the world. So, if in 1980 there were about 1.1 million people wishing to get a foreign higher education, then in 2012 - 4.5 million people. From 2007 to 2015, there has been an almost $50 \%$ increase in the number of foreign students in the world, with three quarters of students from around the world studying in "developed" countries [9].

Today the education of foreign citizens has ceased to be for Russian educational organizations only an item of additional income, this is a reflection of the general quality of training in the educational organization and the demand for the proposed programs. To monitor the effectiveness of universities, the main indicator of international activity is determined by the proportion of the number of foreign students enrolled in the main educational programs of higher education in the total number of students. The need to comply with this criterion determines the compulsory admission for training of foreign citizens in the amount not lower than the established threshold values. In turn, federal and national research universities, as well as universities participating in the "5-100" Project, must necessarily provide for in their development programs a significant increase in the foreign contingent of students.

Today Russian universities are characterized by multidisciplinary international educational activities, including pre-university training of foreign citizens in Russian; the presence of a permanent contingent of foreign students, graduate students and interns studying on a commercial basis (including under contracts with foreign industrial organizations, grants from international organizations, partnerships); stable admission to training specialists for foreign countries under international treaties of the Russian Federation; opening of branches and representative offices abroad.

It should be noted that the structure of the distribution of foreign students in Russian universities has been preserved since Soviet times. An analysis of the latest statistical data shows that the main direction for the Russian higher education internationalization remains the East Asian direction, which is associated with the geopolitical role of Russia in the development of global socio-cultural trends (Fig.1 and Fig.2). And today, the leading positions in the purchase of Russian education are held by the countries of Asia (31.6\%) and Africa (more than $12 \%$ in total). For Russia, the key role is played by the countries that were previously part of the USSR: $45 \%$ of foreign students are citizens of the CIS countries, Georgia, Abkhazia and South Ossetia, the Baltic countries. A significant decrease in the number of foreign students took place in part of the Eastern European and Balkan countries (from 33 to $2 \%$ ) and Latin America. In many ways, these education markets have turned out to be lost for Russia. 


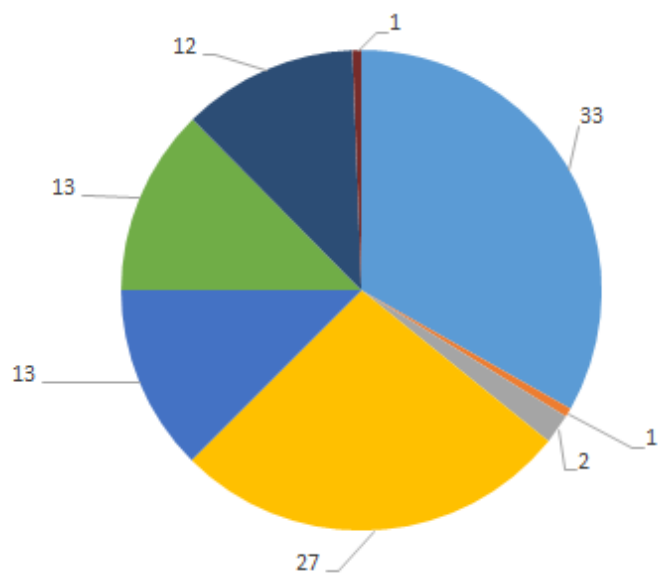

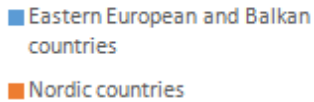

Eastern European and Balkan countries

Nordic countries

- Western European countries

Asian countries

Countries of the Middle East an North Africa

- Sub-Saharan Africa

Latin American countries

Fig. 1. The share of foreign citizens who studied at universities of the USSR [11].
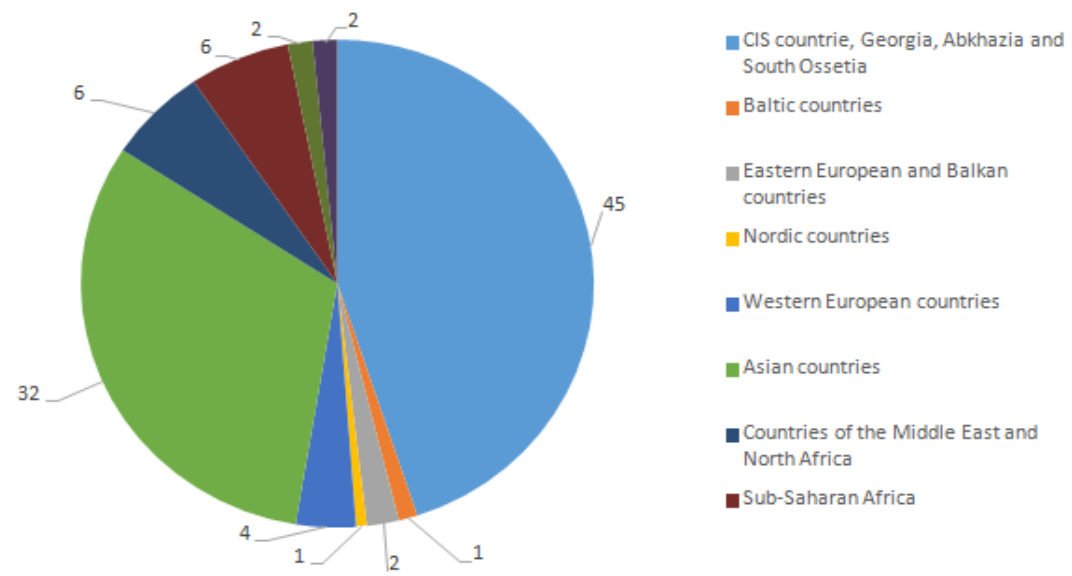

Fig. 2. The share of foreign citizens who studied at Russian universities in 2006/2007 - 2014/2015 [11].

Exporting countries of education are largely specialized in the field of educational programs provided for certain reference groups. The leaders in demand among the educational programs chosen by students are STEM (Science, Technology, Engineering and Mathematics) and Business programs. About 20 percent of all international students study business and management in the United States, while $28 \%$ of all international students study business and management. [10] In Russia, according to the Ministry of Science and Higher Education of the Russian Federation, the majority of foreign students $(21 \%)$ study in medical fields of study, followed by economics and management $(19 \%)$ and the humanities (11\%). Technical specialties (power engineering, computer science, geology, mechanical engineering) are studied by about $13 \%$ of all foreign students in Russia. In the USSR, it was engineering and technical specialties that accounted for a large share $-53 \%$ of foreign students studied according to these programs [11].

Thus, in order to form an effective Russian strategy for working with foreign students, it is possible to recommend developing educational programs from the following enlarged groups: education and pedagogical sciences, economics and management, medicine, health care, applied geology, mining, oil and gas business and geodesy. 
The decisive factor when choosing a country of study for foreign applicants is the reputation of the national higher education system and ratings. In this regard, we can agree with the position that in the conditions of the international market, universities can have two different strategies - internationalization (striving to capture a share of the global market) and regionalization (focus on regional labor markets). At the same time, "not only at the level of national education systems, but also at the level of individual universities, strategic approaches to the development of universities and their mission should be determined, as well as the targeted promotion strategy in international rankings"[12].

At organization level regionalization and internationalization presupposes consistency in the development of higher education systems, the formation of a system of accounting for credits, diplomas, educational levels, a schedule of the educational process, uniform approaches to the qualifications of teachers, the implementation of various kinds of joint programs and academic exchanges. At the regional level, one aspect of export development may include the development of research networks, clusters and projects, and the creation of regional centers of excellence.

An overview of national strategies for the development of education allows us to identify five universal directions for the development of higher education internationalization:

1. provision of education that meets international standards and the formation of a brand of the national education system as having a high quality mark;

2. expanding research activities by strengthening international research networks;

3. promoting cooperation with members of the international community through international non-governmental organizations and international partnership;

4. improving the infrastructure of educational organizations;

5. development of plans for the development of the higher education internationalization in certain areas, reference groups, etc.

In addition to these strategies, it is possible to single out a number of optional directions for the development of higher education internationalization:

1. revision of curricula and presentation of courses on international issues;

2. development of human resources (PPP) and the institutional structure for the implementation of social, economic, cultural projects for the development of higher education internationalization;

3. scientific and cultural cooperation of student organizations and scientific councils of universities;

4. the use of the "best world practices" to update existing educational programs;

5. emphasis on intercultural skills in the design of educational courses;

6. development of intercultural courses;

7. development of adaptation courses for foreign students; specialization of teaching for reference groups of students;

8. exchange of experience between universities in the field of international cooperation;

9. international scientific cooperation between universities;

10. enrichment of the university environment for educational and research activities in accordance with international standards (foreign professors and researchers);

11. planning of educational programs to ensure regional and international cooperation between universities;

12. creation of a support system for foreign students, improvement of the infrastructure of student campuses, migration legislation, funds for supporting talented youth;

13. creation and stimulation of the development of international activities of researchers and young education specialists;

14. providing access to international research projects; 
15. development of IT training, distance formats;

16. implementation of scientific cooperation on the basis of cooperation at the international and regional levels;

17. conducting information campaigns aimed at informing potential students about the benefits of the national education system;

18. development of international and regional cooperation to improve the quality of educational programs.

\section{Conclusion}

At present, Russia is not the leader in terms of total income from the higher education internationalization, but is included in the top 10 countries in terms of the number of foreign students. However, the existing potential of the Russian education internationalization can provide the country with higher values of indicators in this area.

Based on the analysis of foreign strategies to stimulate the higher education internationalization, it is possible to identify five universal areas that need to be implemented in Russia, and these areas are interrelated and cannot be implemented separately:

1. provision of education that meets international standards and the formation of a brand of the national education system as having a high quality mark;

2. expanding research activities by strengthening international research networks;

3. promoting cooperation with the international community through international nongovernmental organizations and international partnerships;

4. improving the infrastructure of educational organizations;

5. development of plans for the development of the higher education internationalization in certain areas, reference groups, etc.

In the context of the Covid-19 pandemic, the priority areas for the development of internationalization are the development of interaction with partners, including through online events and joint scientific research, the development of virtual mobility and internal internationalization and regionalization. Regionalization of higher education is a process of purposeful creation of connections and relationships between participants, structures and systems of the regional higher education. However, within the framework of regionalization, higher education is important as a tool for regional integration that contributes to sustainable regional development. In conditions of the knowledge economy and digitalization, the regionalization of higher education can act as a tool for ensuring economic growth. Regionalization involves the formation of a system of accounting for credits, diplomas, levels of education, the schedule of the educational process, common approaches to the qualification of teachers, the implementation of various types of joint programs and exchanges. At the regional level, one of the aspects of export development may include the development of research networks, clusters and projects, and the creation of regional centers of excellence.

\section{References}

1. Passport of the priority project "Development of the export potential of the Russian education system, http://static.government.ru/

2. P. Altbach, J. Knight, Journal of Studies in International Education, 11 (3-4), 290 (2007)

3. M.C. Wende, The Challenges of University Ranking, http://www.leidenslatest.leidenuniv.nl/ (2006) 
4. N. Healey, Higher Education Quarterly, 67, 2, 180 (2013)

5. I.V. Abankina et al., Global competitiveness of Russian education. Materials for discussion (2017)

6. R.R. Asmyatullin, Bulletin of RUDN, Series: Economics, 2, 99 (2016)

7. O.S. Vinokurova, Human Capital, 9, 27 (2018)

8. A.I. Nefedova, Export of Russian higher education: features of the formation and structuring of demand: dissertation (2017)

9. Project Atlas, http://www.iie.org/ (2015)

10. Education at a Glance OCED report (2017)

11. A.L. Arefiev, F.E. Sheregi, Export of Russian educational services: Statistical collection, 6 (2016)

12. N.L. Antonova, A.D. Sushchenko, Higher Education in Russia, 6, 144 (2020) 